\title{
PERBANDINGAN KINERJA DAN PENGUNGKAPAN ETIKA ISLAM PADA PT BANK MUAMALAT DENGAN PT BANK BRI SYARIAH
}

\author{
Lince Bulutoding \\ Universitas Islam Negeri Alauddin Makassar \\ lince.bulutoding@,uin-alauddin.ac.id \\ Muh. Ruslim Akbar \\ Universitas Islam Negeri Alauddin Makassar \\ ruslimruslimruslim@gmail.com
}

\section{Keywords: \\ Shariah Conformity and \\ Profitability \\ (SCnP), Ethical \\ IdentityIndex(EII), and \\ Islamic Banking.}

\section{Kata Kunci: \\ Kesesuaian dan \\ Profitabilitas Syariah \\ (SCnP), Ethical \\ IdentityIndex (EII), dan \\ Perbankan Syariah.}

\section{ABSTRACT}

This research is aimed to give an comparison and development of performance and disclosure of islamic ethics PT Bank Muamalat and PT Bank BRI Syariah has used the Shariah Conformity and Profitability (SCnP) Method and Ethical Identity Index (EII) during period 2015 until 2016. This research is a quantitative research with descriptive statistical analysis. The result of this study indicate during period 2015 until 2016, performance of PT Bank Muamalat and PT Bank BRI Syariah predicate satisfactory and quite bealthy but has different result. While the comparison and development of islamic ethical disclosures on PT Bank. Muamalat and PT Bank BRI Syariah also show different results on each dimension of disclosure.

\begin{tabular}{l}
\hline ABSTRAK \\
\hline Penelitian ini bertujuan untuk mengetahui perbandingan dan \\
perkembangan kinerja dan pengungkapan etika pada PT Bank \\
Muamalat dan PT Bank BRI Syariah dengan menggunakan metode \\
Shariah Conformity and Profitability (SCnP) dan Ethical Identity Index \\
(EII) periode 2015 dan 2016. Penelitian ini adalah penelitian \\
kuantitatif dengan analisis statistik deskriptif.Hasil menunjukkan \\
bahwa pada tahun 2015 dan 2016, kinerja PT Bank Muamalat dan \\
PT Bank BRI Syariah berpredikat memuaskan dan cukup sehat \\
namun memiliki hasil yang berbeda. Sementara Perbandingan dan \\
perkembangan pengungkapan etika Islam pada PT Bank Muamalat \\
dan PT Bank BRI Syariah juga menunjukkan kondisi yang berbeda \\
pada setiap dimensi pengungkapan.
\end{tabular}

\section{PENDAHULUAN}

Fenomena krisis moneter yang melanda indonesia pada tahun 1998 dan krisis global yang juga terjadi dipenghujung tahun 2008 telah membawa dampak besar pada perbankan pada khususnya dan seluruh perusahaan pada umumnya. Bank-bank dkelola dengan sistem bunganya, namun hal tersebut tidak terjadi pada bank syariah. Hal ini disebabkan karena bank syariah tidak menerapkan prinsip bunga melainkan menggunakan prinsip bagi hasil pada produknya. Sistem bagi hasil yang diterapkan dalam produk-produk bank syariah menyebabkan bank syariah mampu mempertahankan kinerjanya dan tidak hanyut oleh tingkat suku bunga simpanan. Sistem yang dijalankan perbankan syariah juga sangat berbeda dengan sistem perbankan konvensional. Bank konvensional menggunakan sistem bunga yang di dalam ajaran Islam disebut riba. Padahal keharaman riba sudah disebutkan dalam Al-Qur'an. Sehingga, Produk-produk yang ditawarkan bank syariah mampu memberikan tempat bagi 
Lince Bulutoding, Muh. Ruslim Akbar. Perbandingan Kinerja Dan Pengungkapan ...

masyarakat yang belum bisa menerima sistem bank konvensional disebabkan hambatan keyakinan yang dianutnya. Pengembangan perbankan syariah di Indonesia bertujuan untuk menyediakan alternatif pelayanan kepada masyarakat baik dalam bentuk pembiayaan, penyimpanan dana atau kegiatan usaha lainnya yang dilakukan berdasarkan prinsip syariah. Dengan berbagai keunggulan yang dimiliki bank syariah menyebabkan pertumbuhan dan perkembangan perbankan syariah semakin meningkat. Sehingga bank syariah mengalami perkembangan sejak beberapa dekade terakhir dan menjadi salah satu tren dalam dunia keuangan.

Tabel 1:Statistik Pertumbuhan Perbankan Syariah di Indonesia 2009-2015

\begin{tabular}{cccccccc}
\hline Indikasi & $\mathbf{2 0 0 9}$ & $\mathbf{2 0 1 0}$ & $\mathbf{2 0 1 1}$ & $\mathbf{2 0 1 2}$ & $\mathbf{2 0 1 3}$ & $\mathbf{2 0 1 4}$ & $\mathbf{2 0 1 5}$ \\
\hline BUS & 6 & 11 & 11 & 11 & 11 & 12 & 12 \\
UUS & 25 & 23 & 24 & 24 & 23 & 22 & 22 \\
BPRS & 138 & 150 & 155 & 158 & 163 & 163 & 161 \\
\hline
\end{tabular}

Sumber: Otoritas Jasa Keuangan, Juni 2015

Perbankan syariah yang saat ini mengalami perkembangan yang baik juga menunjukkan kinerja yang relatif baik.Tabel 2 menunjukkankinerja Bank Umum Syariah dan Unit Usaha Syariah.

Tabel 2:Rasio Keuangan Bank Umum Syariah dan Unit Usaha Syariah 2009-2015

\begin{tabular}{cccccccc}
\hline Rasio & $\begin{array}{c}\mathbf{2 0 0 9} \\
\mathbf{( \% )}\end{array}$ & $\begin{array}{c}\mathbf{2 0 1 0} \\
\mathbf{( \% )}\end{array}$ & $\begin{array}{c}\mathbf{2 0 1 1} \\
\mathbf{( \% )}\end{array}$ & $\begin{array}{c}\mathbf{2 0 1 2} \\
\mathbf{( \% )}\end{array}$ & $\begin{array}{c}\mathbf{2 0 1 3} \\
\mathbf{( \% )}\end{array}$ & $\begin{array}{c}\mathbf{2 0 1 4} \\
\mathbf{( \% )}\end{array}$ & $\begin{array}{c}\mathbf{2 0 1 5} \\
\mathbf{( \% )}\end{array}$ \\
\hline CAR & 10,77 & 16,25 & 16,63 & 14,13 & 14,42 & 15,74 & 14,09 \\
ROA & 1,48 & 1,67 & 1,79 & 2,14 & 2,00 & 0,79 & 0,89 \\
ROE & 26,09 & 17,58 & 15,73 & 24,06 & 17,24 & 5,85 & 7,98 \\
NPF & 4,01 & 3,02 & 2,52 & 2,22 & 2,62 & 4,33 & 4,73 \\
FDR & 89,39 & 89,67 & 88,94 & 100,00 & 100,32 & 91,50 & 96,52 \\
BOPO & 84,39 & 80,54 & 78,41 & 74,97 & 78,21 & 94,16 & 94,22 \\
\hline
\end{tabular}

Sumber: Otoritas Jasa Keuangan, Tahun 2017

Kinerja bank syariah yang baik akan mewujudkan kepercayaan dari pemangku kepentingan (stakeholder) terhadap dana yang mereka investasikan dan juga stakeholder yang lain (masyarakat, pemerintah, karyawan, dan pihak yang berkepentingan). Menurut Roza (2015), dengan karakter unik yang dimiliki bank syariah, tentunya pengukuran kinerja bank syariah harus berbeda dengan bank konvensional. Sehingga dibutuhkan pengukuran kinerja bagi bank syariah tidak hanya dari sisi keuntungan namun juga dari sisi lain. Misalnya pengukuran dari sisi kepatuhan syariah, kinerja sosial, atau pengukuran dari sisi tujuan syariah.

Namun, selama ini pengukuran kinerja perbankan di Indonesia hanya dibatasi pengukuran dari sisi keuangan berdasarkan metode pengukuran kinerja yang ada. Berdasarkan Peraturan Otoritas Jasa Keuangan (POJK) Nomor 8/POJK.03/2014 tentang Penilaian Tingkat Kesehatan Bank Umum Syariah dan Unit Usaha Syariah, bahwa Faktor yang menjadi penilaian Tingkat Kesehatan Bank Umum Syariah adalah Profil Risiko, Corporate Governance, Rentabilitas, dan Permodalan. Pengukuran kinerja dengan menggunakan metode tersebut kurang tepat jika digunakan untuk mengukur kinerja bank syariah. Sebab penilaian kinerja bank syariah tidak hanya dinilai dari profitabilitasnya saja namun juga kesesuaian dengan syariah islam. Kesadaran akan sasaran ini, kemudian menghasilkan alat ukur yang khas bagi bank syariah. Kuppusami et al. (2010) mencoba merepresentasikan hal tersebut melalui metode pengukuran yang disebut Shariah Conformity and Profitability (SCnP) untuk menguji kinerja keuangan bank dari Malaysia, Bahrain, Kuwait, dan Jordan.

SCnP merupakan model penilaian kinerja yang menggabungkan prinsip perbankan syariah yaitu dengan mengukur ketaatan syariah (shariah conformity) dan prinsip perbankan 
konvensional dengan mengukur profitabilitas (profitability). Selain melakukan pengukuran kinerja atas laporan keuangan, bank syariah juga diharapkan mampu mempertanggung jawabkan aktivitas operasional bank dalam laporan tahunan yang dipublikasikan ke masyarakat. Oleh sebab itu Baydoun \& Wilett (2000) menyarankan agar lebih transparan dalam memenuhi pengungkapan laporan tahunan bank syariah, yang mana informasi tersebut berguna bagi pengguna laporan tahunan dan para pemangku kepentingan dalam pengambilan keputusan.

Dalam pandangan islam, penyajian informasi baik dalam laporan keuangan maupun laporan tahunan tidak boleh ada unsur penyembunyian atas informasi yang ada. Sehingga informasi tersebut tidak di ketahui oleh salah satu pihak pemakai laporan. Ketidakjelasan terjadi apabila ada pihak yang merubah sesuatu yang seharusnya dilaporkan menjadi tidak dilaporkan. Dalam Al-Qur`an dijelaskan pencatatan laporan harus pasti dan tidak ada unsur penipuan. Dalam hal informasi yang diungkapkan dalam laporan tahunanperbankan syariah tentunya berbeda dengan perbankan konvensional. Hal ini disebabkan karena perbankan syariah memiliki tanggung jawab moral yang tinggi dibandingperbankan konvensional. Penelitian yang dilakukan Hannifa \& Hudaib (2007) merumuskan delapan dimensi pengungkapan berdasarkan nilai-nilai etika islam yang seharusnya diungkapkan dalam laporan tahunan perbankan syariah yaitu dimensi pernyataan visi dan misi, dimensi dewan komisaris dan manajemen puncak, dimensi produk dan layanan, dimensi zakat, sedekah dan pinjaman kebajikan, dimensi komitmen terhadap karyawan, dimensi komitmen terhadap debitur, dimensi komitmen terhadap masyarakat, dan dimensi Dewan Pengawas Syariah (DPS).

\section{LANDASAN TEORI}

\section{a) Shariah Enterprise Theory}

Shariah Enterprise Theory merupakan enterprise theory yang telah diinternalisasi dengan nilai-nilai Islam guna menghasilkan teori yang transendental dan lebih humanis (Triyuwono, 2003). Enterprise theory, seperti telah dibahas oleh (Meutia, 2010), merupakan teori yang mengakui adanya pertanggungjawaban tidak hanya kepada pemilik perusahaan saja melainkan kepada kelompok stakeholders yang lebih luas. Lebih lanjut Meutia menjelaskan bahwa terdapat beberapa dimensi yang ditawarkan oleh shariah enterprise theory dalam pengungkapan tanggung jawab sosial perusahaan, terutama oleh perbankan syariah. Dimensi-dimensi akuntabilitas vertikal dan akuntabilitas horizontal. Akuntabilitas vertikal ditujukan hanya kepada Tuhan. Sedangkan akuntabilitas horizontal ditujukan kepada tiga pihak, yaitu direct stakeholders, indirect stakeholders, dan alam. Pihak-pihak yang disebut direct stakeholders menurut shariah enterprise theory adalah nasabah dan karyawan. Sedangkan pihak yang termasuk indirect stakeholders menurut shariah enterprise theory adalah komunitas.

\section{b) Metode Shariah Conformity and Profitability (SCnP)}

Shariah Conformity and Profitability (SCnP) merupakan metode pengukuran kinerja keuangan pada perbankan syariah. Menurut Kuppusamy et al. (2010), metode penilaian kinerja yang menggabungkan prinsip perbankan syariah yaitu dengan mengukur ketaatan syariah (shariah conformity) dan prinsip perbankan konvensional dengan mengukur profitabilitas (profitability). Metode SCnP dengan menggunakan enam indikator penilaian yaitu Return On Asset (ROA), Return On Equity (ROE), Profit Margin, Investasi Halal, Pendapatan Halal dan Rasio Bagi Hasil.

\section{c) Ethical Identity Index (EII)}

Ethical Identity Index (EII) adalah metode digunakan untuk menilai perbandingan antara informasi yang seharusnya diungkapkan dan informasi yang telah diungkapkan bank syariah 
Lince Bulutoding, Muh. Ruslim Akbar. Perbandingan Kinerja Dan Pengungkapan ...

pada laporan tahunan yang berdasarkan nilai-nilai etika islam. Haniffa \& Hudaib (2007), merumuskan lima fitur informasi pengungkapan perbankan syariah berdasarkan nilai-nilai etika islam sekaligus sebagai pembeda identitas antara bank syariah dan bank konvensional. Yaitu nilai dan filososfi yang mendasari, penyediaan produk dan jasa yang bebas bunga, transaksi yang sesuai dengan syariah, fokus pada tujuan pembangunan dan sosial, dan kewajiban untuk direviu oleh Dewan Pengawas Syariah.

\section{METODE PENELITIAN}

Pendekatan yang digunakan dalam penelitian ini adalah pendekatan kuantitatif dengan analisis statistik deskriptif. Dalam penelitian ini, peneliti akan mengukur dan membandingkan kinerja dan pengungkapan etika Islam bank syariah. Metode pengukuran yang digunakan dalam mengukur kinerja bank syariah adalah Metode SCnP yang digunakan oleh Kuppusamy et al. (2010). Sedangkan untuk mengukur pengungkapan etika Islam bank syariah pada laporan tahunan, peneliti menggunakan Ethical Identity Index yang dikembangkan oleh Haniffa \& Hudaib (2007).Objek dalam penelitian ini adalah PT Bank Muamalat dan PT Bank BRI Syariah. Sumber data yang digunakan adalah data sekunder yang dikumpulkan dari laporan keuangan dan laporan tahunan PT Bank Muamalat dan PT Bank BRI Syariah periode 20152016 yang diperoleh dari situs resmi (Official Website) masing-masing bank.Dalam metode $\mathrm{SCnP}$ digunakan dua indikator penilaian yaitu indikator shariah conformity dan indikator profitability. Dalam penelitian ini untuk mengukur tingkat profitabilitas dalam metode SCnP hanya digunakan satu indikator penilaian yaitu ROA.

a. Indikator Shariah Conformity

1) Investasi Halal

Rasio investasi halalmerupakan ukuran aspek kehalalan dan keberhasilan pelaksanaan prinsip dasar bank syariah, yakni bebas dari unsur maysir, gharar, dan riba serta aliran dana hanya disalurkan ke sektor yang halal. Investasi halal dapat dihitung dengan rumus:

$$
\text { Islamic Investment }=\frac{\text { Islamic Investment }}{\text { Islamic Investment }+ \text { non-Islamic Investment }}
$$

2) Pendapatan Halal

Rasio pendapatan halal menunjukkan presentase dari seberapa banyak pendapatan halal yang didapatkan dibandingkan dengan total pendapatan yang diperoleh bank syariah, dihitung dengan rumus:

$$
\text { Islamic Income }=\frac{\text { Islamic Income }}{\text { Islamic Income }+ \text { non-Islamic Income }}
$$

3) Rasio Bagi Hasil

Rasio ini mengukur seberapa besar bank syariah mampu menyalurkan dana ke sektor produktif dengan skema bagi hasil. Rasio bagi hasil dapat dihitung dengan rumus :

$$
\text { Profit Sharing Ratio }=\frac{\text { Mudharabab }+ \text { Musyarakah }}{\text { Total Financing }}
$$

untuk menilai predikat kinerja ketaatan syariah yang diperoleh bank syariah maka penelitian ini menggunakan penilaian kinerja sebagai berikut 
AL-MASHRAFIYAH: Jurnal Ekonomi, Keuangan dan Perbankan Syariah Volume 2, Nomor 1 April 2018

Tabel 3Kriteria Penilaian Ketaatan Syariah

\begin{tabular}{cc}
\hline Skor Rata-Rata & Predikat \\
\hline $0 \leq \mathrm{x}<1$ & Sangat Tidak Memuaskan \\
$1 \leq \mathrm{x}<2$ & Tidak Memuaskan \\
$2 \leq \mathrm{x}<3$ & Kurang Memuaskan \\
$3 \leq \mathrm{x}<4$ & CukupMemuaskan \\
$4 \leq \mathrm{x}<5$ & Memuaskan \\
$\mathrm{x}=5$ & Sangat Memuaskan \\
\hline
\end{tabular}

Sumber : Aisjah dan Hadianto (2013)

b. Indikator Profitability

1) Return on Assets (ROA)

Indikator yang umum yang digunakan untuk mengukur kinerja dimana rasio ini menunjukkan perbandingan atau rasio antara rata-rata total aset, dan pendapatan sesudah pajak. Return on Assets (ROA) dihitung dengan rumus :

$$
\mathrm{ROA}=\frac{\text { Net Income }}{\text { Average Total Assets }}
$$

Tabel 4:Kriteria Penilaian ROA

\begin{tabular}{lc}
\hline \multicolumn{1}{c}{ Rasio } & Predikat \\
\hline $\mathrm{ROA}>1,5 \%$ & Sangat Sehat \\
$1,25 \%<\mathrm{ROA} \leq 1,5 \%$ & Sehat \\
$0,5 \%<\mathrm{ROA} \leq 1,25 \%$ & Cukup Sehat \\
$0 \%<\mathrm{ROA} \leq 0,5 \%$ & Kurang Sehat \\
$\mathrm{ROA} \leq 0 \%$ & Tidak Sehat \\
\hline
\end{tabular}

Sumber: SE BI No. 6/23/DPNP, Tahun 2017

Dalam Ethical Identity Index peneliti menggunakan acuan penilaian berdasarkan penelitian Haniffa \& Hudaib (2007) seperti dalam tabel 5.

Tabel 5:Indikator Ethical Identity Index

a. Dimensi Pernyataan Visi dan Misi

1) Komitmen beroperasi sesuai dengan prinsip syariah.

2) Komitmen memberikan hasil sesuai prinsip syariah.

3) Fokus memaksimalkan keuntungan pemegang saham.

4) Melayani kebutuhan umat muslim sekarang.

5) Melayani kebutuhan umat muslim masa depan.

6) Komitmen terlibat hanya pada investasi yang diperbolehkan islam.

7) Komitmen hanya pada kegiatan pendanaan yang diperbolehkan islam.

8) Komitmen untuk memenuhi kewajiban sesuai pernyataan kontrak.

9) Apresiasi terhadap pemegang saham dan pelanggan.

b. Dimensi Dewan Komisaris dan Manajemen Puncak

1) Keberadaan nama anggota dewan komisaris.

2) Posisi anggota dewan komisaris.

3) Foto anggota dewan komisaris.

4) Profil anggota dewan komisaris.

5) Kepemilikan saham anggota dewan komisaris.

6) Jabatan ganda diantara anggota dewan komisaris.

7) Keanggotaan dewan komite audit. 
Lince Bulutoding, Muh. Ruslim Akbar. Perbandingan Kinerja Dan Pengungkapan ...

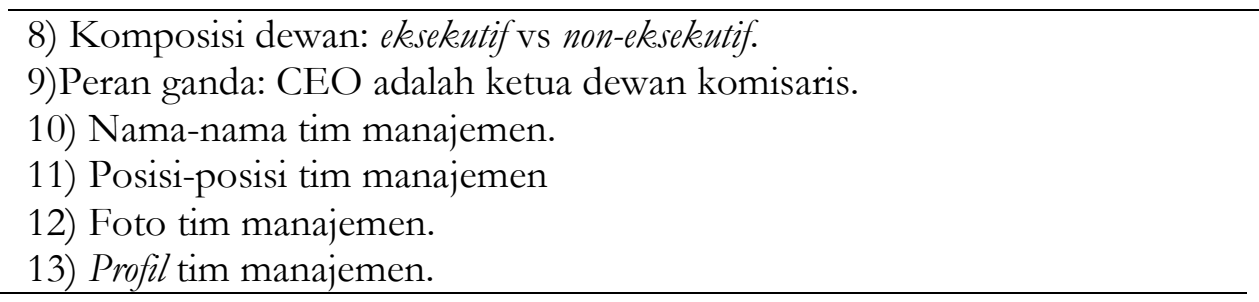
c. Dimensi Produk dan Layanan

1) Tidak ada keterlibatan dalam kegiatan tidak halal.

2) Presentase laba dari keterlibatan tidak halal.

3) Alasan keterlibatan dalam kegiatan tidak halal.

4) Penanganan kegiatan tidak halal.

5) Memperkenalkan produk baru.

6) Persetujuan Dewan Pengawas Syariah (DPS) sebelum produk baru.

7) Dasar konsep syariah atas produk baru.

8) Daftar/definisi produk.

9) Kegiatan investasi umum.

10) Kegiatan pembiayaan umum.

\section{d. . Dimensi Zakat, Sedekah dan Pinjaman Kebajikan}

1) Pertanggungjawaban zakat.

2) Jumlah zakat yang dibayarkan.

3) Sumber dana zakat.

4) Penggunaan dana dan pemanfaatan zakat.

5) Saldo zakat yang tidak didistribusikan.

6) Alasan adanya saldo zakat yang tidak didistribusikan.

7) Pengesahan sumber dan penggunaan dana zakat oleh DPS.

8) Pengesahan oleh DPS bahwa zakat telah dihitung sesuai syariah.

9) Jumlah zakat yang dibayarkan oleh individu.

10) Sumber dana sedekah.

11) Penggunaan dana sedekah.

12) Sumber dana qardh hasan.

13) Penggunaan dana qardh hasan.

14) Kebijakan penyediaan danaqardh hasan.

15) Kebijakan dana gardh hasan yang tidak kembali.

\section{e. Dimensi Komitmen Terhadap Karyawan}

1) Penghargaan terhadap karyawan.

2) Jumlah karyawan.

3) Kebijakan kesempatan yang sama.

4) Kesejahteraan karyawan.

5)Pelatihan syariah.

6) Pelatihan lain.

7)Pelatihanpelajar/skema perekrutan.

8)Pelatihan moneter/keuangan.

9) Hadiahbagi karyawan.

f. Dimensi Komitmen Terhadap Debitur

1) Kebijakan hutang.

2) Jumlah hutang yang dihapuskan.

3) Jenis kegiatan peminjaman umum.

4) Jenis kegiatan peminjaman khusus.

g. Dimensi Komitmen Terhadap Masyarakat

1) Cabang khusus perempuan. 

2) Menciptakan lapangan kerja.
3) Dukungan terhadap organisasi yang memberikan manfaat bagi masyarakat.
4) Partisipasi dalam kegiatan sosial pemerintahan.
5) Mensponsori kegiatan masyarakat.
6) Komitmen untuk peran sosial.
7) Penyelenggaraan konferensi ekonomi islam.

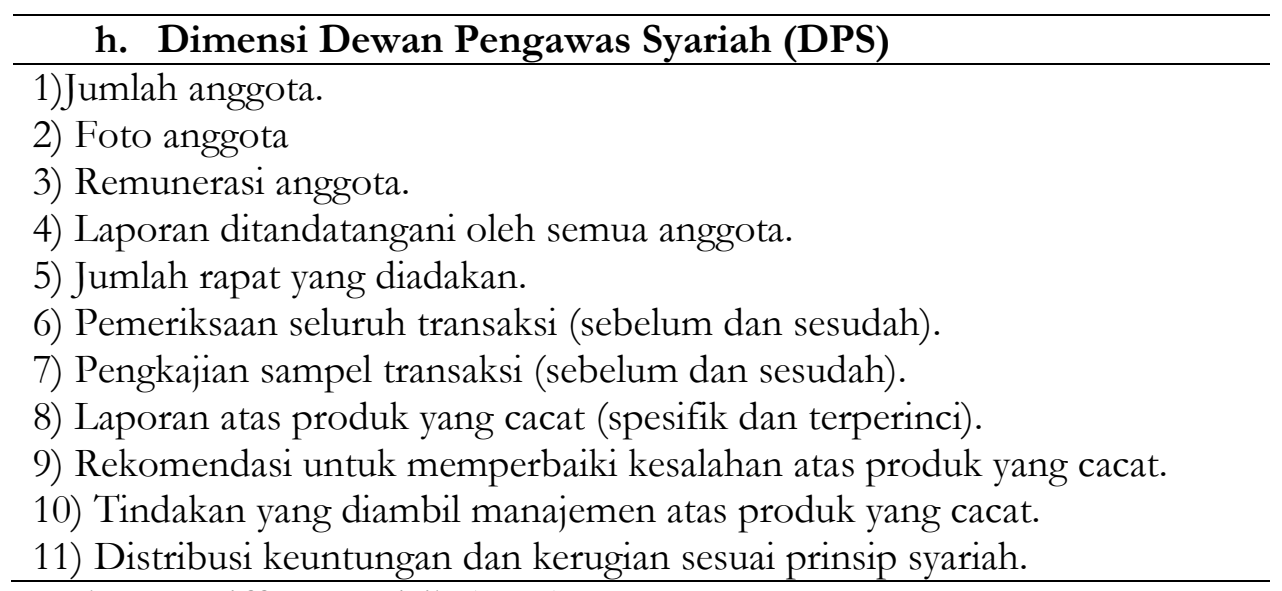

Indikator dan instrumen pengumpulan data dilakukan dengan checklist. Pendekatan yang digunakan merupakan pendekatan dengan skala dikotomus, dimana poin penilaian akan diberi poin satu jika indikator dikomunikasikan, dan poin nol jika indikator tidak dikomunikasikan. Untuk mendapatkan hasil dari penelitian mengenai pengungkapan nilai-nilai etika islam maka dapat menggunakan rumus dari Ethical Identity Index (EII).

Dimana:

$$
E I I J=\frac{\sum_{t=1}^{n j} \mathrm{Xij}}{\mathrm{nj}}
$$

$\mathrm{EIIj}=$ Ethical Identity Index (EII)

$\mathrm{nj}=$ jumlah konstruk atau item $\mathrm{n}$ yang diungkapkan oleh perusahaan $\mathrm{j}$

$\mathrm{X} i \mathrm{j}=1$ jika pada tahun ke $\mathrm{i}$ konstruk atau item diungkapkan, 0 jika pada tahun ke $\mathrm{i}$ konstruk atau item tidak diungkapkan

Alat analisis data digunakan untuk menjawab permasalahan yang ada dan mencapai tujuan penelitian yang telah diuraikan sebelumnya. Analisis data pada penelitian ini menghasilkan data deskriptif kuantitatif. Alat analisis yang digunakan dalam penelitian ini adalah:

\section{Analisis SCnP Model}

Dalam menempatkan posisi bank sampel pada analisis hasil penelitian, SCnP menggunakan model empat kuadran dengan menggunakan aplikasi SPSS 21, yang ditentukan sebagai berikut. 
Lince Bulutoding, Muh. Ruslim Akbar. Perbandingan Kinerja Dan Pengungkapan ...

Gambar 1:SCnP Model

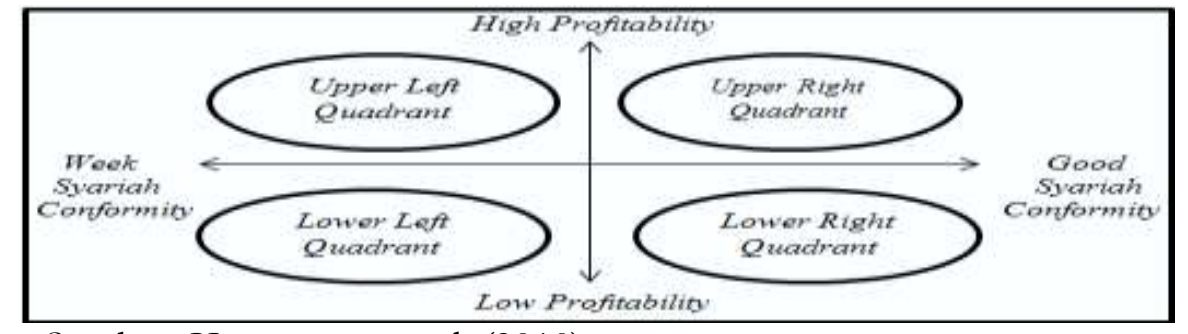

Sumber: Kuppusamy et al. (2010)

a. Jika hasil analisis Sharia Confirmity and Profitabiity menunjukkan hasil yang positif $(>0)$, maka terletak pada kuadran URQ (Upper Right Quadrant) yang menunjukkan bahwa bank sampel memiliki tingkat ketaatan syariah dan profitabilitas yang tinggi.

b. Jika hasil analisis Sharia Conformity tinggi $(>0)$ dan Profitability rendah $(<0)$, maka terletak pada kuadran LRQ (Lower Right Quadrant) yang menunjukkan bahwa bank sampel memiliki tingkat ketaatan syariah yang tinggi namun profitabilitas yang rendah.

c. Jika hasil analisis Shariah Confomity rendah $(<0)$ dan Profitability tinggi $(>0)$, maka terletak pada kuadran ULQ (Upper Left Quadrant) yang menunjukkan bahwa bank sampel memiliki tingkat ketaatan syariah yang rendah namun profitabilitas yang tinggi.

d. Jika hasil analisis Shariah Conformity and Profitability menunjukkan hasil yang negative $(<0)$, maka terletak pada kuadran LLQ (Lower Left Quadrant) yang menunjukkan bahwa bank sampel memiliki tingkat ketaatan syariah dan profitabilitas yang rendah.

2. Analisis Ethical Identity Index (EII)

Analisis hasil perhitungan disajikan dalam bentuk tabel menggunakan Ms. Excel 2010. Hasil EII yang tinggi menunjukkan bahwa perusahaan telah mengadopsi strategi komunikasi yang sesuai nilai-nilai etika Islam. sementara EII yang rendah menunjukkan kebutuhan untuk memperbaiki strategi komunikasi untuk meningkatkan citra etika serta reputasi bank syariah dalam mendapatkankeuntungan kompetitif.

HASIL DAN PEMBAHASAN

a. Shariah Conformity and Profitability (SCnP)

1) Shariab Conformity

Tabel6:Rasio Investasi Halal tahun 2015-2016

\begin{tabular}{cccccc}
\hline \multirow{2}{*}{ NO } & \multirow{2}{*}{ Nama Bank } & \multicolumn{2}{c}{$2015(\%)$} & \multicolumn{2}{c}{$2016(\%)$} \\
\cline { 3 - 5 } & & Nilai & Predikat & Nilai & Predikat \\
\hline 1. & PT Bank Muamalat & 97,23 & Memuaskan & 92,22 & Memuaskan \\
2. & PT Bank BRI Syariah & 98,15 & Memuaskan & 98,17 & Memuaskan \\
\hline
\end{tabular}

Sumber: Data Diolah, 2017

Secara keseluruhan, PT Bank Muamalat dan PT Bank BRI Syariah hampir memiliki investasi halal dari seluruh investasi yang dimilikinya. Sebagaimana terlihat pada tabel yang presentase investasi halalnya berada diatas angka 90\%. Bank BRI Syariah 
AL-MASHRAFIYAH: Jurnal Ekonomi, Keuangan dan Perbankan Syariah Volume 2, Nomor 1 April 2018

memiliki nilai investasi halal lebih tinggi dari Bank Muamalat selama periode 2015 dan 2016.

Tabel7:Rasio Pendapatan Halal tahun 2015-2016

\begin{tabular}{cccccc}
\hline \multirow{2}{*}{ NO } & \multirow{2}{*}{ Nama Bank } & \multicolumn{2}{c}{$\mathbf{2 0 1 5 ( \% )}$} & \multicolumn{2}{c}{ 2016(\%) } \\
\cline { 3 - 5 } & PT Bank Muamalat & Nilai & Predikat & Nilai & Predikat \\
\hline 1. & \multirow{2}{*}{ PT } & Memuaskan & 99,92 & Memuaskan \\
2. & PT Bank BRI Syariah & 99,97 & Memuaskan & 99,97 & Memuaskan \\
\hline
\end{tabular}

Sumber: Data Diolah, 2017

Secara keseluruhan, PT Bank Muamalat dan PT Bank BRI Syariah hampir memiliki pendapatan halal dari seluruh pendapatan yang dimilikinya. Sebagaimana terlihat pada tabel yang presentase pendapatan halalnya rata-rata 99\%. Bank Muamalat dan Bank BRI Syariah juga berusaha untuk meminimalisir pendapatan tidak halal. Hal itu dibuktikan dengan peningkatan pendapatan halal. Ini berarti bahwa pendapatan tidak halal menurun pada kedua bank tersebut.

Tabel8:Rasio Bagi Hasil tahun 2015-2016

\begin{tabular}{cccccc}
\hline \multirow{2}{*}{ NO } & Nama Bank & Nilai & Predikat & Nilai & Predikat \\
\cline { 3 - 5 } 1. & PT Bank Muamalat & 52,12 & $\begin{array}{c}\text { Kurang } \\
\text { Memuaskan }\end{array}$ & 52,28 & $\begin{array}{c}\text { Kurang } \\
\text { Memuaskan }\end{array}$ \\
2. & PT Bank BRI Syariah & 36,42 & $\begin{array}{c}\text { Tidak } \\
\text { Memuaskan }\end{array}$ & 35,80 & $\begin{array}{c}\text { Tidak } \\
\text { Memuaskan }\end{array}$ \\
\hline
\end{tabular}

Sumber: Data Diolah, 2017

Presentase Rasio Bagi Hasil pada Bank Muamalat mengalami kenaikan walaupun tidak signifikan. Hal ini menunjukkan bahwa Bank Muamalat semakin baik dalam membagi keuntungan yang diperoleh dengan proporsi keuntungan dan kerugian ditanggung bersama. Sementara Bank BRI Syariah belum mampu meningkatkan skema bagi hasil dari seluruh aktivitas pembiayaan.

\section{2)Profitability}

Profitabilitas pada SCnP Model menggunakan tiga indikator didalamnya yaitu Return On Asset (ROA), Return On Equity (ROE) dan Profit Margin Ratio. Dalam Penelitian ini, profitabilitas diukur hanya menggunakan indikator Return On Asset (ROA). ROA yang digunakan untuk menunjukkan kemampuan bank dalam menghasilkan keuntungan dari pengelolaan aset. Hasil pengukuran ROA pada PT Bank Muamalat dan PT Bank BRI Syariah periode 2015-2016 disajikan pada tabel berikut:

Tabel 9: Return On Asset (ROA) tahun 2015-2016

\begin{tabular}{cccccc}
\hline \multirow{2}{*}{ No } & \multirow{2}{*}{ Nama Bank } & \multicolumn{2}{c}{ 2015(\%) } & \multicolumn{2}{c}{ 2016(\%) } \\
\cline { 3 - 6 } & & Nilai & Predikat & Nilai & Predikat \\
\hline 1. & PT Bank Muamalat & 0,20 & Cukup Sehat & 0,22 & Cukup Sehat \\
2. & PT Bank BRI Syariah & 0,76 & Cukup Sehat & 0,95 & Cukup Sehat \\
\hline
\end{tabular}


Lince Bulutoding, Muh. Ruslim Akbar. Perbandingan Kinerja Dan Pengungkapan ...

Pengukuran profitabilitas sebagai bentuk pengukuran atas aktivitas atau tugas yang telah dilakukan secara periodik berdasarkan standar pengukuran kinerja yang digunakan. Kinerja menunjukkan sesuatu yang berhubungan dengan kekuatan serta kelemahan suatu perusahaan.dari hasil penelitian dalam tabel 9 di atas menunjukkan bahwa kedua bank tersebut memiliki pengembalian aset berada pada cukup sehat. Artinya baik Bank Muamalat maupun bank BRI Syariah, menunjukkan pengembalian aset yang cukup sehat.

\section{b. Analisis Perbandingan dan Perkembangan Kinerja Keuangan dengan Metode SCnP}

Dari beberapa perhitungan rasio yang telah didapatkan dari berbagi indikator keuangan untuk Sharia Conformity and Profitability, disimpulkan menjadi satu tabel untuk memperjelas kinerja keuangan pada PT Bank Muamalat dan PT Bank BRI Syariah sebagai berikut :

1) Analisis Perbandingan Kinerja Keuangan Tahun 2015

\section{Grafik 1:SCnP Model Tahun 2015}

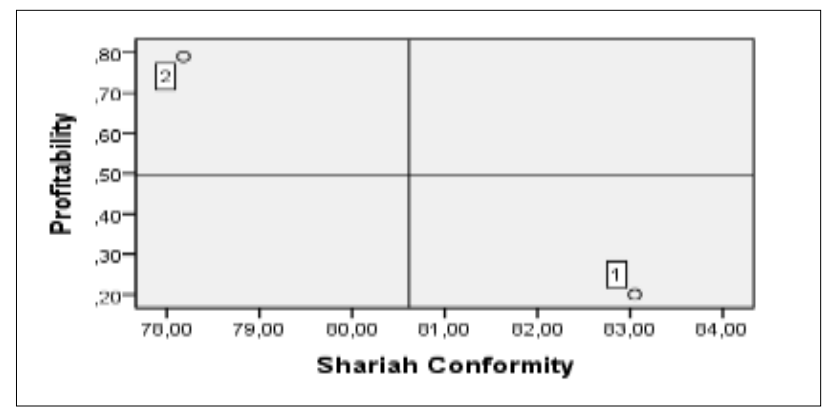

Sumber: Data Diolah, 2017

Pada Grafik SCnP Model Tahun 2015, terlihat bahwa PT Bank Muamalat (1) berada pada Lower Right Quadrant (LRQ) yang mengindikasikan bank sampel memiliki tingkat ketaatan syariah yang tinggi namun tingkat profitabilitasnya rendah tingkat ketaatan syariah yang tinggi dikarenakan indikator investasi halal dan pendapatan halal rata-rata mencapai 98,51\%. Namun nilai ROA hanya berada pada angka $0,20 \%$. Sementara PT Bank BRI Syariah (2) berada pada Upper Left Quadrant (ULQ) yang mengindikasikan bank sampel memiliki tingkat profitabilitas tinggi namun tingkat ketaatan syariahnya rendah. hal ini terjadi karena indikator Bagi Hasil PT. Bank BRI Syariah yang rendah pada tahun 2015 juga berdampak pada ketaatan syariah. Berdasarkan predikat, nilai shariah conformity dan profitability PT Bank Muamalat dan PT Bank BRI Syariah pada tahun 2015 sama-sama memuaskan dan cukup sehat. Adapun data dari Pengukuran SCnP Model untuk tahun 2015 adalah sebagai berikut :

Tabel 10: Nilai SCnP tahun 2015

\begin{tabular}{cccccc}
\hline \multirow{2}{*}{ No } & \multirow{2}{*}{ Nama Bank } & \multicolumn{2}{c}{ Shariah Conformity(\%) } & \multicolumn{2}{c}{ Profitability(\%) } \\
\cline { 3 - 6 } 1. & PT Bank Muamalat & 83,05 & Predikat & Nilai & Predikat \\
\hline 2. & PT Bank BRI Syariah & 78,18 & Memuaskan & 0,20 & Cukup Sehat \\
\end{tabular}

Sumber: Data Diolah, 2017 
2) Analisis Perbandingan Kinerja Keuangan Tahun 2016

Grafik 2:SCnP Model Tahun 2016

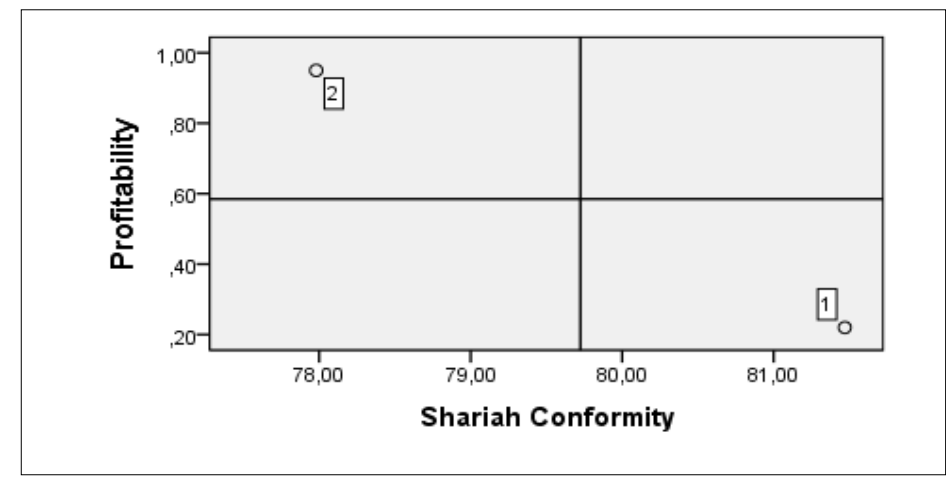

Sumber: Data Diolah, 2017

Pada Grafik SCnP Model Tahun 2016, terlihat bahwa PT Bank Muamalat (1) masih berada pada Lower Right Quadrant (LRQ) yang mengindikasikan bank sampel memiliki tingkat ketaatan syariah yang tinggi namun tingkat profitabilitasnya rendah.tingkat ketaatan syariah yang tinggi dikarenakan indikator investasi halal dan pendapatan halal rata-rata mencapai 96,07\% walaupun lebih rendah dari tahun sebelumnya. Namun nilai ROA berada pada angka $0,22 \%$ namun tetap mengalami peningkatan walau tidak signifikan. Sementara PT Bank BRI Syariah (2) berada pada Upper Left Quadrant (ULQ) yang mengindikasikan bank sampel memiliki tingkat profitabilitas tinggi namun tingkat ketaatan syariahnya rendah. hal ini terjadi karena indikator bagi hasil yang masih rendah juga berdampak pada ketaatan syariah bank tersebut. Namun nilai ROA bank BRI Syariah selalu lebih tinggi dari Bank Muamalat yang mengakibatkan kinerja profitabilitas juga lebih baik.

Berdasarkan predikat, nilai shariah conformity dan profitability PT Bank Muamalat dan PT Bank BRI Syariah pada tahun 2016 sama-sama memuaskan dan cukup sehat. Berdasarkan perkembangan kinerja, pada tahun 2015 dan 2016, PT Bank Muamalat dan PT Bank BRI Syariah masing-masing mengalami penurunan Shariah Conformity meski tidak signifikan. Namun dari sisi profitabilitas PT Bank Muamalat dan PT Bank BRI Syariah masing-masing mengalami kenaikan nilai meski tidak signifikan.Adapun data dari Pengukuran SCnP Model untuk tahun 2016 adalah sebagai berikut :

Tabel 11: Nilai SCnP tahun 2016

\begin{tabular}{cccccc}
\hline \multirow{2}{*}{ NO } & \multirow{2}{*}{ Nama Bank } & \multicolumn{2}{c}{ Shariah Conformity $(\%)$} & \multicolumn{2}{c}{ Profitability $(\%)$} \\
\cline { 3 - 5 } & & Nilai & Predikat & Nilai & Predikat \\
\hline 1. & PT Bank Muamalat & 81,47 & Memuaskan & 0,22 & Cukup Sehat \\
& & & & \\
2. & PT Bank BRI Syariah & 77,98 & Memuaskan & 0,95 & Cukup Sehat \\
\hline
\end{tabular}

Sumber: Data Diolah, 2017

\section{c. Analisis Perbandingan dan Perkembangan Pengungkapan Etika Islam PT Bank Muamalat Dengan PT Bank BRI Syariah}

Hasil eksplorasi perbandingan Pengungkapan Etika Islam PT Bank Muamalat dengan PT Bank BRI Syariah tahun 2015, dapat dilihat pada tabel sebagai berikut: 
Lince Bulutoding, Muh. Ruslim Akbar. Perbandingan Kinerja Dan Pengungkapan ...

Tabel 12: Nilai Ethical Identity Index

PT Bank Muamalat dan PT Bank BRI Syariah tahun 2015

\begin{tabular}{clcc} 
No & \multicolumn{1}{c}{ Dimensi } & PT Bank Muamalat & PT BankBNI Syariah \\
\hline 1 & Visi dan Misi & 0,22 & 0,33 \\
2 & Dewan Komisaris dan & & \\
& Manajemen Puncak & 1 & 1 \\
3 & Produk dan Layanan & 0,9 & 0,8 \\
4 & Zakat, Sedekah, dan Pinjaman & 0,86 & 0,86 \\
& Kebajikan & 1 & 0,77 \\
5 & Komitmen terhadap Karyawan & 1 & 1 \\
6 & Komitmen terhadap Debitur & 0,71 & 0,71 \\
7 & Komitmen terhadap Masyarakat & 1 & 1 \\
8 & Dewan Pengawas Syariah (DPS) & 0,84 & 0,82 \\
\hline & Total Nilai EII & &
\end{tabular}

Sumber: Data Diolah, 2017

Berdasarkan Tabel 12, Pada tahun 2015 pengungkapan etika Islam PT. Bank Muamalat lebih tinggi dari PT. Bank BRI Syariah. Namun, pada tahun 2016 pengungkapan etika kedua bank adalah sama. Pada tahun 2015 hingga 2016 tidak terjadi perubahan pada nilai pengungkapan etika islam Bank Muamalat. Hal ini diakibatkan karena tidak adanya perubahan pengungkapan setiap dimensi. Secara keseluruhan pada tahun 2015 hingga 2016 jumlah pengungkapan yang dilakukan PT Bank Muamalat masih sama yakni sebanyak 66 indikator dari total 78 indikator penilaian. Pada tahun 2015 dan 2016, terjadi peningkatan pada nilai pengungkapan etika islam Bank BRI Syariah yakni sebesar 0,02 pada dimensi komitmen terhadap karyawan. Secara keseluruhan pada tahun 2015 jumlah pengungkapan yang dilakukan sebanyak 64 indikator dan jumlah pengungkapan bertambah pada tahun 2016 menjadi 66 indikator dari total 78 indikator penilaian.

Tabel 13:Nilai Ethical Identity Index PT Bank Muamalat dan PT Bank BRI Syariah tahun 2016

\begin{tabular}{clcc} 
No & \multicolumn{1}{c}{ Dimensi } & PT Bank Muamalat & PT Bank BNI Syariah \\
\hline 1 & Visi dan Misi & 0,22 & 0,33 \\
2 & Dewan Komisaris dan & 1 & 1 \\
& Manajemen Puncak & 0,9 & 0,8 \\
3 & Produk dan Layanan & 0,86 & 0,86 \\
4 & Zakat, Sedekah, dan Pinjaman & 1 & 1 \\
& Kebajikan & 1 & 1 \\
5 & Komitmen terhadap Karyawan & 0,71 & 0,71 \\
6 & Komitmen terhadap Debitur & 1 & 1 \\
7 & Komitmen terhadap Masyarakat & 0,84 & 0,84 \\
8 & Dewan Pengawas Syariah (DPS) &
\end{tabular}

Sumber: Data Diolah, 2017

Selama dua periode, dimensi yang paling banyak diungkapkan oleh kedua bank adalah Dimensi Dewan Komisaris dan Manajemen Puncak, Komitmen terhadap Karyawan, Komitmen terhadap Debitur, dan DPS. Dimensi yang paling sedikit diungkapkan adalah 
dimensi visi dan misi. Nilai-nilai pengungkapan etika Islam pada PT Bank Muamalat dan PT Bank BRI Syariah sebagai bukti bahwa PT Bank Muamalat dan PT Bank BRI Syariah telah melaksanakan dimensi yang ditawarkan oleh shariah enterprise theory dalam pengungkapan tanggung jawab sosial perusahaan, terutama untuk perbankan syariah. Dimensi-dimensi tersebut meliputi akuntabilitas vertikal dan akuntabilitas horizontal. Akuntabilitas vertikal ini ditujukan kepada Tuhan. Sedangkan akuntabilitas horizontal ditujukan kepada tiga pihak, yaitu direct stakeholders, indirect stakeholders, dan alam.

\section{PENUTUP}

\section{a. Simpulan}

Perbandingan kinerja PT Bank Muamalat dengan PT Bank BRI Syariah berada pada kondisi yang berbeda-beda, walaupun memiliki predikat yang sama. Pada tahun 2015 dan 2016, PT Bank Muamalat memiliki tingkat ketaatan syariah yang tinggi namun profitabilitas yang rendah. Sementara pada tahun 2015, perbandingan pengungkapan etika islam PT Bank Muamalat lebih baik dari PT Bank BRI Syariah Ini berarti bahwa PT. Bank Muamalat tidak mengejar profit semata tetapi harus memegang teguh etika dan kepatuhan syariah. Adapun PT Bank BRI Syariah memiliki tingkat ketaatan syariah yang rendah namun memiliki profitabilitas yang tinggi. Ini berarti bahwa PT. Bank BRI Syariah masih sementara menyesuaikan diri terhadap etika dan ketaatan syariah. Adapun pada tahun 2016, perbandingan pengungkapan etika islam PT. Bank Muamalat dengan PT. Bank BRI Syariah memiliki nilai yang sama.Perkembangan kinerja dari sisi tingkat ketaatan syariah PT. Bank Muamalat dan PT Bank BRI Syariah mengalami penurunan. Namun, tingkat profitabilitas PT. Bank Muamalat dan PT. Bank BRI Syariah mengalami peningkatan. Sementara perkembangan pengungkapan etika islam PT. Bank Muamalat adalah tetap dan Perkembangan pengungkapan etika islam PT. Bank BRI Syariah mengalami peningkatan.

\section{b. Saran}

Berdasarkan hasil penelitian, maka peneliti dapat memberikan saran sebagai berikut:

1. Penelitian ini hanya menggunakan periode penelitian selama 2 tahun yaitu 2015 dan 2016. Pada penelitian selanjutnya diharapkan menggunakan jangka waktu penelitian yang lebih lama agar diperoleh hasil yang lebih tepat dan objektif.

2. Peneliti membatasi penelitian model SCnP pada aspek Return On Equity (ROE) dan Profit Margin dengan hanya menggunakan indikator Return On Asset (ROA). Oleh karena itu, diharapkan penelitian selanjutnya dapat menganalisis mengenai kedua aspek tersebut dalam menilai kinerja Profitabilitas perbankan syariah agar didapatkan hasil yang lebih akurat dalam penilaian kinerjanya.

3. Bagi Bank Umum Syariah di Indonesia untuk lebih meningkatkan kinerja keuangannya dengan tetap memperhatikan ketaatan syariah sesuai dengan prinsip Islam dengan mengurangi segala hal yang bersifat tidak halal dalam aktivitas usahanya. Adapun implikasi penelitian ini adalah sebagai berikut:

a) Penelitian ini akan memberikan implikasi bagi perbankan syariah lainnya untuk semakin tunduk kepada etika islam dengan melihat kriteria yang dipakai sebagai indikator dalam penelitian ini.

b) Penelitian ini akan memberikan informasi kepada para nasabah untuk memilih bank yang memiliki kepatuhan terhadap etika islam yang tinggi. 
Lince Bulutoding, Muh. Ruslim Akbar. Perbandingan Kinerja Dan Pengungkapan ...

\section{DAFTAR PUSTAKA}

Aggarwal, R. K. dan Yousef. 2000. Islamic Banks and Investment Financing, Journal of Money, Credit, and Banking.

Aisjah, Siti dan Agustian Eko Hadianto. 2013. Performance Based Islamic Performance Index (Study on the Bank Muamalat Indonesia and Bank Syariah Mandiri). Asia-Pacific Management and Business Application.

Amalia, Fitri. 2014. Etika Bisnis Islam:Konsep dan Implementasi pada Pelaku Usaha Kecil. AlIqtishad,Vol. VI No. 1

Ascarya, dan Diana Yumanita. 2005. Bank Syariab: Gambaran Umum. Jakarta: Pusat Pendidikan dan Studi Kebanksentralan (PPSK) Bank Indonesia.

Awaluddin, Murtiadi. 2013. Effect of AuditorIndependence and Competence on Job Satisfaction andPerformance Inspection Auditor Makassar. Journal ofManagerial Vo. 1, No. December 1, 2013: 13-23.

Awaluddin, M. (2013). Pengaruh Independensi dan Kompetensi Auditor Terhadap Kepuasan Kerja dan Kinerja Auditor Inspektorat Kota Makassar. Jurnal Assets, 3.

Bank Indonesia. 2004. Surat Edaran Bank Indonesia No. 6/23/DPNP Peribal Sistem Penilaian Tingkat Kesehatan Bank Umum. 31 Mei 2004. Jakarta.

Baydoun, N. dan Willet. 2000. Islamic Corporate Reports. ABACUS, 36 (1).

Burhanuddin, Hamam. 2014. Etika Bisnis Menurut Islam (Suatu Telaab Material-Immaterial Oriented).Etika Ekonomi dan Bisnis. Perspektif Agama-Agama di Indonesia. Geneva: Globethics.net.

Dasuki,Rima Elya dan Wahyudin. 2010. Etika Bisnis dalam Perspektif Islam. Co-Value,Volume 1 No. 2.

Fitria,Soraya dan Dwi Hartanti. 2010. Islam dan Tanggung Jawab Sosial: Studi PerbandinganPengungkapan Berdasarkan Global Reporting Initiative Indeks dan Islamic Social Reporting Indeks.Simposium Nasional Akuntansi XIII Purwokerto.

Hameed, Shahul. 2004. Alternative Disclosure and Performance for Islamic Bank's. Proceeding of The Second Conference on Administrative Science: Meeting The Challenges of The Globalization Age.

Haniffa, Roszaini dan Hudaib Mohammad. 2007. Exploring the Ethical Identity of Islamic Banks via Communication in Annual Reports. Journal of Business Ethics.

Hidayatullah. 2014. Manajemen Investasi Bank Syari'ah.Human Falab,Volume 1. No. 2.

Kasmir. Analisis Laporan Kenangan. Jakarta: Rajawali Pers,2009.

Khasanah, Anita Nur. Pengarub Intellectual Capital dan Islamicity Performance Index terbadapKinerja Kenangan Perbankan Syariah di Indonesia. Jurnal Nominal, Volume V Nomor 1(2016).

Kuppusamy, M., A. Saleh., S dan Samudhram, A. Measurement of Islamic Banks Performance Using a Syariah Conformity and Profitablity Model. Review of Islamic Economics, Vol. 13 No. 2 (2010).

Kusumo,Yunanto Adi.Analisis Kinerja Kenangan Bank Syariah Mandiri Periode 2002-2007 (dengan Pendekatan PBI No. 9/1/PBI/2007).La_Riba Jurnal Ekonomi Islam, Vol. II, No 1 (2008).

Laporan Tahunan, Bank Muamalat Indonesia, 2015-2016.

Laporan Tahunan, Bank Rakyat Indonesia Syariah, 2015-2016.

Meilani, Sayekti Endah Retno, Dita Andraenydan AnimRahmayati. Analisis Kinerja Perbankan Syariah di Indonesia dengan Menggunakan Pendekatan Islamicity Indices. Syariah Paper Accounting FEB UMS, (ISSN: 2460-0784).

Meutia, Inten. Shariah Enterprise Theory sebagai Dasar Pengungkapan Tanggung Jawab Sosial untuk. Bank Syariah. Disertasi Tidak Dipublikasikan,Doktor Ilmu Akuntansi Program Pascasarjana, Universitas Brawijaya, 2010.

Muhammad, Rifqi. Akuntansi Kenangan Syariah. Yogyakarta: P3EI Press, 2008 
AL-MASHRAFIYAH: Jurnal Ekonomi, Keuangan dan Perbankan Syariah Volume 2, Nomor 1 April 2018

Muhson, Aji. Teknik Analisis Kuantitatif.Diakses pada tanggal 17November, 2016 pukul 15.58 wita, dari http://www.distrodoc.com.

Oktaviana, Ulfi Kartika dan RomiFaslah. Faktor Penentu Keberlanjutan Pengungkapan Etika di Bank Syariah di Indonesia.

Otoritas Jasa Keuangan. Statistik Perbankan Syariah 2014 dan Juni 2015.

Pascual, Jordi Surroca dan Josep, A. Tribo.Corporate Ethical Identity as a Determinant of Firm Performance: A Test of Mediating Role of Stakeholder Satisfaction. Journal of Business Ethics, Vol. 76(2007).

Putra, Relista Andrianto dan Aria Farahmita. Analisis Ethical Identity Index Sebagai Pengukuran Tingkat Pengungkapan Etika pada Perbankan Syariah di Indonesia pada Periode 2010-2011. Program Ekstensi Akuntansi. Fakultas Ekonomi Universitas Indonesia,2013.

Ratnaputri, Widiya.The Analysis of Islamic Bank Financial Performance By Using Camel, Shariah Conformity and Profitability (SCnP).Jumal Dinamika Manajemen, Vol. 4, No. 2 (2013).

Republik Indonesia. Undang-Undang Republik Indonesia Nomor 21 Tabun 2008 tentang Perbankan Syariah.

Roza, Ida.Analisis Perbandingan Kinerja Perbankan Syariah dengan Metode Indeks Maqasid Syariah dan Camel. Tesis. Yogyakarta: UIN Sunan Kalijaga, 2015.

Sarwono, Jonathan.Metode Penelitian Kuantitatif \& Kualitatif. Yogyakarta: Graha Ilmu. Edisi Pertama, 2006.

Sukardi, Budidan Taufiq Wijaya. Corporate Ethical Identity Perbankan Syariah di Indonesia. Jurnal TS AQAFAH, 2014.

Triyuwono, Iwan. Sinergi Oposisi Biner: Formulasi Tujuan Dasar Laporan Kenangan Akuntansi Syaria'ah. IQTISAD Journal of Islamic Economics, Vol. 4, No. 1 (2003). 